\title{
FORECASTING CORN PRODUCTION IN SERBIA USING ARIMA MODEL
}

\author{
Ivana Ilićc , Sonja Jovanovic ${ }^{2}$, Vesna Janković Milic ${ }^{3}$
}

\begin{abstract}
Summary
Agricultural crop production is closely related to climate, as a decisive success factor. Temperature fluctuations and changes in the volume of precipitation are the main factors affecting the growth and development of crops, and, ultimately, the quantity produced. Corn is the most common crop necessary to provide for domestic needs, and a strategic product for export. Production of corn in the period from 1947 to 2014 in Serbia had an oscillatory trend, with significant jumps and falls in production. The subject of this paper is the forecasting of future trends in corn production in Serbia. Building on the subject, the purpose of this paper is to create the model for forecasting future corn production and establishingits trends.
\end{abstract}

Key words: corn production, export chances, Box Jenkins methodology, ARIMA model, Serbia

JEL: $Q 11, C 53, Q 17$

\section{Introduction}

Agricultural sector has a traditional significance within the Serbian economy, which is why it is often seen as a branch of economy with great potential. In addition to its importance in providing food for the local population and their social and political development over time, while ensuring balanced regional development, it has very important economic implications. Great importance of agricultural sector for the Serbian economy is confirmed by its share in total employment, GDP, and export.

In the structure of agricultural production, special place belongs to crop production,

1 Ivana Ilić M.Sc., Ph.D. student, University of Niš, Faculty of Economics, Kralja Aleksandra Ujedinitelja Square no. 11, Niš, Serbia, Phone: +381 645734 347, E-mail: ivanica1404@yahoo.com

2 Sonja Jovanović Ph.D., Associate Professor, University of Niš, Faculty of Economics, Kralja Aleksandra Ujedinitelja Square no. 11, Niš, Serbia, Phone: +381 18528 655, E-mail: sonja.jovanovic@eknfak.ni.ac.rs

3 Vesna Janković - Milić Ph.D., Associate Professor, University of Niš, Faculty of Economics, Kralja Aleksandra Ujedinitelja Square no. 11, Niš, Serbia, Phone: +381 18528 655, E-mail: vesna.jankovic@eknfak.ni.ac.rs

EP 2016 (63) 4 (1141-1156) 
which accounts for almost $70 \%$ of total agricultural production. Such a large share of crop production stems from a very fertile agricultural land that covers large areas in Serbia. It is believed that agricultural land is the greatest natural resource and an essential element of agricultural activities, whose capacity and quality ultimately affect the volume of agricultural production and the level of crop yield (Subić et al., 2005).

The most important agricultural crops in Serbia are corn, wheat, sunflower, sugar beet, soya, potatoes, apples, plums, and grapes. Corn is the most common crop species, necessary to provide for domestic needs, and a strategic product for export. Trends on the international market of agricultural products have led to significant changes in the sowing structure in Serbia in recent years, with the structure of areas under grains experiencing redistribution and growth in the share of corn. This change is justified by the increase in grains prices on the world market, thus increasing the motivation of a large number of farmers to produce corn.

The amount of corn produced in our country is sufficient to meet domestic needs, so that corn is one of the leading export products of Serbia, and is largely marketed in CEFTA countries. In 2015, a record of three million tons of exported corn was reached, which has made Serbia one of the 10 largest exporters of this culture. The value of generated export is important for our economy and is around 100 million euros (Serbian Chamber of Commerce, 2015).

Production of corn in the period from 1947 to 2014 in Serbia had an oscillatory trend, with significant jumps and falls in production. In the 1952 it is recorded the lowest yield of 829,620 tons, while in 1986 there was a record corn yield of 8,062,020 tons (Statistical Office of the Republic of Serbia, 2015). Bearing in mind the potential of our country for the production of corn and the importance of this culture as an export product, the subject of this paper is the forecasting of future trends in corn production in Serbia. Building on the subject, the purpose of this paper is to create the statistical model for forecasting future corn production and establishingits trends.

\section{Importance of corn production in Serbia}

Agriculture is the most important economic branch in Serbia. In the gross domestic product, agriculture and food industry account for $12.3 \%$ (agricultural production with $7.9 \%$ and food industry with $4.4 \%$ ) and the main export surplus is achieved through agricultural production. If one takes into account overall contribution of agriculture to other sectors of the economy, particularly the manufacturers of inputs and raw materials, this share exceeds $40 \%$ of total GDP. The total agrarian trade of Serbia with the world in 2014 amounted to 4705.7 million USD, 3066.9 million relating to export and 1638.8 million USD to import. Compared to the previous year, export of agriculture has increased by about 9.5\% (Serbian Chamber of Commerce, 2015).

On the export side of the foreign agricultural trade of Serbia, the leading position during 2014 belonged to corn, followed by raspberries, sugar, tobacco, sunflower oil, wheat, and apples. For years, corn has been economically the most important cash crop, 
standing for Serbian "export gold". The exported quantities of corn place our country in the top ten world exporters of corn (Žita Srbije, 2014).

Corn is one of the most important cash crops in the world, with universal and economic significance and use, primarily in human and livestock nutrition and meat processing industry. On almost all world continents, corn is grown on about 140 million hectares per year. A large part of sowing areas in Serbia is covered with corn. Of $68 \%$ of the land under grains, 39\% is under this crop. Although areas under grains have experienced constant trends over the years, there have been changes in the structure in favor of corn, which is contrary to the trends prevailing in the world (Agricultural Marketing Information System of Serbia, 2014). Changes in sowing structure have been caused by the price of corn on the world market, which increased producers' interest in its production and thus led to an increase in the total area planted under corn by about 10\% (Agriculture and Rural Development Strategy of the Republic of Serbia for the period 2014-2024). In addition to the price, increase in the level of corn production was influenced by the low technology requirements and increased crop yields over the years.

The primary objective of corn production is to obtain high and stable yields, both quantitatively and qualitatively. Taking into account different production areas of corn cultivation, production technology needs to be adapted to specific climatic conditions, soil, and other environmental factors, so that the potential of habitats and genotypes could be utilized to the fullest extent (Tabaković, 2012). Corn is grown in our country under rainfed conditions, so that years with less precipitation bring the decreased and lower-quality yield.

For the successful cultivation of corn, there are favorable conditions in most agroecological regions in our country. In addition to general growing conditions, corn production is largely affected by seedlings, i.e. seed. The production of mercantile corn today relies on the use of hybrid seeds, with a long world history dating from 1921, which has been used in our country since 1950s (Lekić et al., 2004). Hybrid seed is characterized by high yield potential, stability, and adaptability (Borojević, 1991), and is very suitable for different growing conditions. Using modern knowledge in the field of corn genetics, breeding and seed production, hybrid combinations of corn arecreated, which can meet the requirements of modern agricultural producers, and are characterized by dry grain and green corn mass, as well as the stability of yield and resistance to diseases and insects. In addition to the volume and stability of production, the purpose and use-value of corn hybrids must be taken into account (Sabovljević et al., 2008). Closely associated with the level of production over the years and the price of corn is the production of pork. The competitiveness of pork from Serbia is conditioned by the lower price of corn as the main raw material for its production (Agriculture and Rural Development Strategy of the Republic of Serbia for the period 2014-2024).

Seen in the long run, the average production of corn, as the most common crop in Serbia, has stagnated over the years. The main reason for this situation in the domain of production is reflected in agrotechnology i.e. absence of agro-technical measures 
during dry periods (Glamočlija, 2007). Factors that negatively affect corn yield are: fragmentation of land, growing together with vegetables, insufficient irrigation, obsolete machinery, aging of agricultural workforce, discouraging agricultural policy (Đekić, 2010).

The main driver of positive trends in the agricultural sector is the production and export of corn. The average production of corn over the past decade in Serbia is around 6.1 million tons, which indicates rich yield in the past years. Record yield of the most competitive Serbian product was recorded in 2014, when 7,951,583 tons were produced (Statistical Office of the Republic of Serbia, 2015). According to Index Mundi, judging by corn production, in 2014 Serbia was ranked $14^{\text {th }}$ out of 122 countries included in the analysis (Table 1). Out of the quantity produced, about 3 million tons were exported, with the largest importers of corn from Serbia being Greece, Macedonia, Bosnia and Herzegovina, and Cyprus. The value generated from exports is significant, amounting to around 468 million USD (Serbian Chamber of Commerce, 2015).

Table 1. Ranking of countries based on corn production in 2014 by Index Mundi

\begin{tabular}{|c|c|c|}
\hline Rank & Country & Production (1000MT) \\
\hline 1. & USA & $361,091.00$ \\
\hline 2. & China & $21,5500.00$ \\
\hline 3. & Brazil & $75,000.00$ \\
\hline 4. & EU-27 & $74,160.00$ \\
\hline 5. & Ukraine & $28,450.00$ \\
\hline 6. & Mexico & $24,000.00$ \\
\hline 7. & Argentina & $24,000.00$ \\
\hline 8. & India & $22,500.00$ \\
\hline 9. & Canada & $11,500.00$ \\
\hline 10. & Russia & $11,325.00$ \\
\hline 11. & South Africa & $11,300.00$ \\
\hline 12. & Indonesia & $7,400.00$ \\
\hline 13. & The Philippines & $7,800.00$ \\
\hline 14. & Serbia & $7,700.00$ \\
\hline 15. & Nigeria & \\
\hline & & \\
\hline
\end{tabular}

Source: Index Mundi (2014), Corn Production by Country in 1000 MT,http://www.indexmundi. com/agriculture/? commodity $=$ corn

Comparing corn yield in 2015 to the 2014, one can notice a substantial decline by almost $25 \%$, and if considered in relation to the ten-year average, production fell by $10 \%$. The cause of declining corn production is primarily reflected in high air temperature and extremely dry year, which has, generally speaking, caused severe damage in agricultural production. Unlike 2014, a reduction of export volumes to around 2 million tons should be expected in 2015. The price of corn has increased slightly, both on the domestic and foreign markets, caused by drought. The largest average share in the export of crops from Serbia belongs to corn, $81 \%$, and, at the same time, it is the most exported 
agricultural product. Another reason why Serbia is one of the major exporters of corn is that animal husbandry is at a very low level, and the decreased corn production affects the reduction of stocks of animal feed, given its percentage participation in production (Graph 1.).

Graph 1. Largest corn exporters in 2014 (in 1,000 metric tons)

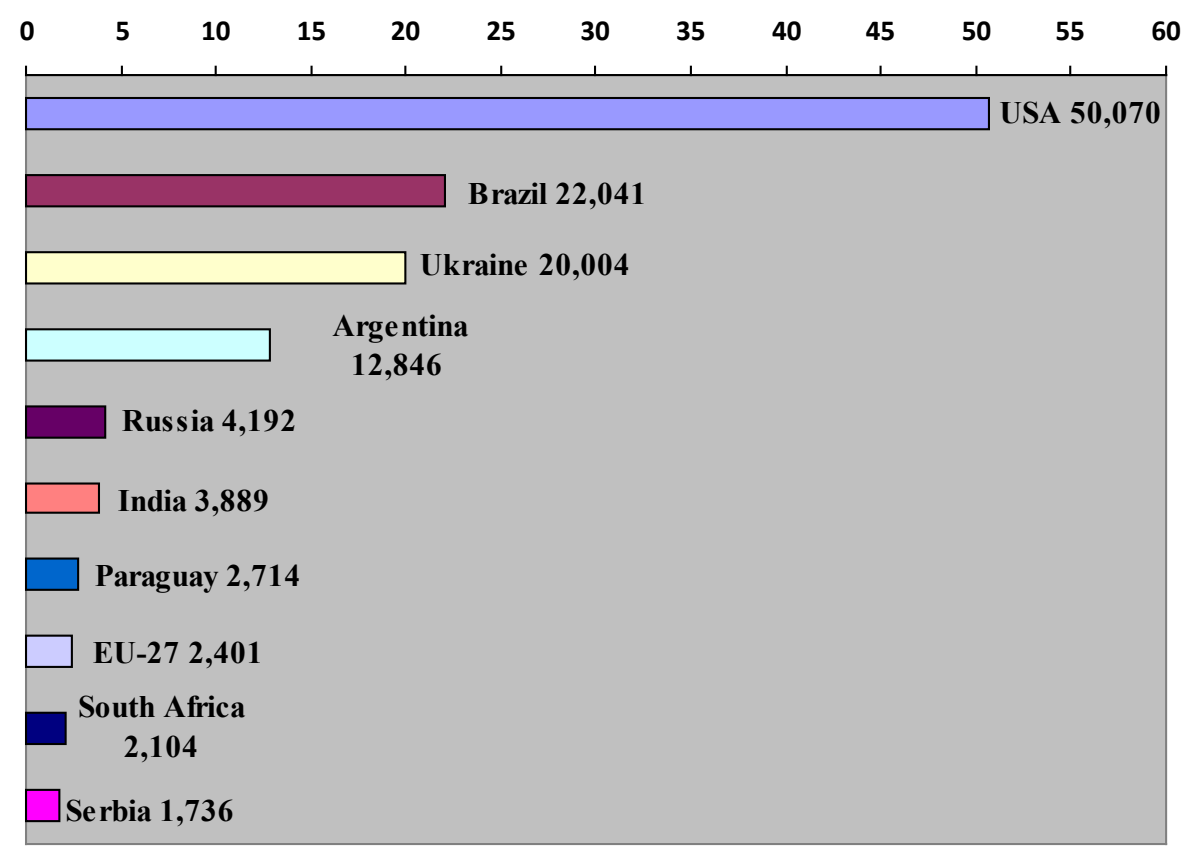

Source:The Statistic Portal, 2015 http://www.statista.com/statistics/254299/top-global-cornexporters/

Global corn consumption is projected to increase to repeated record levels every year. In addition to meat production, which is also expected to continue its long-term rise, corn will remain a central component of nutrition in many parts of the world. Industrial demand for this crop will in the future be on the rise, because it is used in the production of fuel, ethanol, and it is expected that the main increase will be linked to an increased global economic activity and supporting production of starch (International Grains Council, 2015). Positive trends in corn production should continue in the future, and become a chance for the recovery of Serbian agriculture, as well as the economy in general, because of huge export opportunities (Mladenović et al., 2016). However, in the conduct of foreign policy of importance to consider the limits which stem from the measures of agricultural protectionism. (Marković, Marković, 2014)

Forecasting corn production in the coming period can be done by using ARIMA models, which are very popular for forecasting and modeling of various phenomena whose data consists of time series. ARIMA models are used to forecast agricultural 
production (Padhan, 2012), wheat growing (Iqbal et al., 2005), tourism demand (Baldigara, Mamula, 2015), exchange rate (Olanrewaju et al., 2014), consumer price index (Etuk, 2012; Akpanta, Okorie, 2015), water production (Okasha, Abu Shanab, 2014). The main objective of this research was to, based on data time series of the analyzed phenomena, develop the most appropriate ARIMA model by which it is possible to forecast future trends.

\section{Research methodology}

The subject of analysis in this paper is the forecasting of future trends in corn production in Serbia, based on the past production volume. Building on the research subject, the purpose of this paper is to create model for forecasting future corn production and establishing its trends, while extracting external factors influencing production. In other words, the model chosen as the most favorable should point to the production volume that should be expected in the next three years, based on the production in the period 1947-2014.

Information base of research consists of data of the Statistical Office of the Republic of Serbia on corn production in the analyzed period. Given that the selected data make a time series, statistical models that can describe the principles in the behavior of time series and forecast future trends based on the known past situation are used. The work relied on ARIMA model.

Special emphasis is on Box Jenkins methodology for forecasting the corn production trend in Serbia in the three years (2015-2017). Box Jenkins methodology is a powerful method of determination of mathematical models of different stochastic variables. In essence, it is a methodology of systematic multi-phase modeling for the identification and evaluation of models with the aim of finding the best adjusted data time series and making forecasts. The main advantage of Box Jenkins methodology involves obtaining big data for the analyzed empirical time series using a small number of parameters. Further, it can be used for modeling both the stationary and non-stationary time series with and without seasonal component (Kostić et al.,2016).

ARIMA model was developed in 1970 by Box and Jenkins, to identify, estimate, and diagnose dynamic time series models in which time is a key variable. ARIMA model is used for modeling and forecasting of non-stationary time series, after the process of differentiation. Using the ARIMA model is limited to long time series of "high frequency" (years, months, weeks, days...), is useful for forecasting, but not for structural understanding of the phenomena or simulation of scenarios.

\section{Results and discussion}

To forecast the future corn production for the purpose of research, the work applied ARIMA model. Given that the analysis focuses on annual data on corn production in Serbia, the appropriate non-seasonal ARIMA model is applied. ARIMA model was derived from the standard Box Jenkins model, and includes autoregressive (AR) and 
moving-average factors (MA) in the modeling process. ARIMA model includes nonseasonal factors in the multiplicative model according to the following formula:

$$
\operatorname{ARIMA}=(\mathrm{p}, \mathrm{d}, \mathrm{q})
$$

where $\mathrm{p}$ - non-seasonal component of autoregressive model (AR),

$\mathrm{d}$ - non-seasonal differentiation,

$\mathrm{q}$ - non-seasonal component of moving-average model (MA).

Box Jenkins methodology was developed through three successive phases, (1) model identification, (2) model estimation, and (3) model diagnostics and forecasting. During the first phase of identification, stationarity of time series is checked, since the basic prerequisite for creating the ARIMA model is the stationary time series - the observed time series must have constant variance and mean value over time.

Based on the graphic presentation of the correlogram and the Augmented Dickey-Fuller Unit Root Test (ADF), non-stationarity of the time series selected for the analysis has been confirmed. The downward trend of the coefficients of autocorrelation and partial correlation after the first lag points to the non-stationarity of the selected time series (Figure 1).

Figure 1. Correlogram Production

Sample: 19472017

Included observations: 68

\begin{tabular}{|c|c|c|c|c|c|c|c|c|}
\hline \multicolumn{2}{|c|}{ Autocorrelation } & \multicolumn{3}{|c|}{ Partial Correlation } & \multirow{2}{*}{$\frac{A C}{0.608}$} & \multirow{2}{*}{$\begin{array}{c}\text { PAC } \\
0.608\end{array}$} & \multirow{2}{*}{$\begin{array}{c}\text { Q-Stat } \\
26.297\end{array}$} & \multirow{2}{*}{$\frac{\text { Prob }}{0.000}$} \\
\hline 1 & & 1 & & 1 & & & & \\
\hline 1 & & 1 & $\square$ & 2 & 0.605 & 0.373 & 52.718 & 0.000 \\
\hline 1 & & 1 & $\square$ & 3 & 0.598 & 0.258 & 78.903 & 0.000 \\
\hline 1 & $\square$ & I & $\square$ & 4 & 0.565 & 0.140 & 102.62 & 0.000 \\
\hline 1 & $\square$ & 1 & I & 5 & 0.552 & 0.107 & 125.67 & 0.000 \\
\hline 1 & $\square$ & 1 든 & I & 6 & 0.449 & -0.101 & 141.15 & 0.000 \\
\hline 1 & $\square$ & 1 당 & 1 & 7 & 0.388 & -0.131 & 152.92 & 0.000 \\
\hline I & $\square$ & 1 다 & 1 & 8 & 0.336 & -0.116 & 161.90 & 0.000 \\
\hline 1 & $\square$ & 1 & 1 & 9 & 0.330 & 0.016 & 170.71 & 0.000 \\
\hline 1 & $\square$ & 1 & 1 & 10 & 0.262 & -0.034 & 176.32 & 0.000 \\
\hline 1 & $\square$ & 1 & 1 & 11 & 0.187 & -0.070 & 179.23 & 0.000 \\
\hline 1 & $\square$ & 1 & 1 & 12 & 0.175 & 0.017 & 181.84 & 0.000 \\
\hline 1 & יו & 1 & 1 & 13 & 0.183 & 0.108 & 184.73 & 0.000 \\
\hline 1 & 1 & 1 다 & 1 & 14 & 0.075 & -0.117 & 185.22 & 0.000 \\
\hline 1 & ○ & I & 1 & 15 & 0.101 & 0.047 & 186.14 & 0.000 \\
\hline 1 & 1 & 1 무 & 1 & 16 & 0.002 & -0.124 & 186.14 & 0.000 \\
\hline 1 & I & 1 & 1 & 17 & 0.002 & -0.033 & 186.14 & 0.000 \\
\hline 1 & I & 1 & 1 & 18 & -0.010 & -0.023 & 186.15 & 0.000 \\
\hline 1 & 1 & 1 & 1 & 19 & -0.015 & 0.085 & 186.17 & 0.000 \\
\hline 1 & I & I & 1 & 20 & -0.021 & 0.070 & 186.22 & 0.000 \\
\hline I & 1 & $\sqsubset$ & 1 & 21 & -0.174 & -0.249 & 189.28 & 0.000 \\
\hline 1 & 1 & 1 & ا & 22 & -0.032 & 0.159 & 189.39 & 0.000 \\
\hline 1 다 & 1 & I & 1 & 23 & -0.088 & 0.008 & 190.21 & 0.000 \\
\hline 1 당 & 1 & 1 - & 1 & 24 & -0.130 & -0.092 & 192.02 & 0.000 \\
\hline 1 只 & I & 1 & I & 25 & -0.100 & 0.031 & 193.13 & 0.000 \\
\hline $1 \square$ & 1 & 10 & 1 & 26 & -0.158 & -0.046 & 195.95 & 0.000 \\
\hline 1 口 & I & 1 & I & 27 & -0.130 & -0.007 & 197.91 & 0.000 \\
\hline $1 \square$ & 1 & 1 다 & 1 & 28 & -0.149 & -0.090 & 200.55 & 0.000 \\
\hline
\end{tabular}

Source:Authors 'presentation by using the EViews 7 program

EP 2016 (63) 4 (1141-1156) 
In ADF tests, null and alternative hypotheses are set. The null hypothesis is confirmed by the existence of unit root, i.e. non-stationarity of the time series. The obtained value of the ADF test statistic is -1.784200 , which is less than the critical value for the error level of 5\%, which indicates the acceptance of the null hypothesis and the existence of the non-stationarity (Table 2.).

Table 2. ADF test for Production

Null Hypothesis: PRODUCTION has a unit root Exogenous: Constant Lag Length: 2 (Automatic - based on SIC, maxlag=10)

\begin{tabular}{lccc}
\hline \hline & t-Statistic & Prob.* \\
\hline \hline Augmented Dickey-Fuller test statistic & -1.784200 & 0.3850 \\
\hline Test critical values: & $1 \%$ level & -3.534868 & \\
& $5 \%$ level & -2.906923 & \\
& $10 \%$ level & -2.591006 & \\
\hline \hline
\end{tabular}

*MacKinnon (1996) one-sided p-values.

Source:Authors 'presentation by using the EViews 7 program

In order to achieve stationarity, transformation of time series was firstly performed, i.e. calculation of logarithmic values, and the first-order differentiation. Correlogram and the selected test after transformation confirm the stationarity of the observed time series (Figure 2.).

Figure 2. Correlogram Logproduction

\begin{tabular}{|c|c|c|c|c|c|c|c|c|}
\hline \multicolumn{2}{|c|}{ Autocorrelation } & \multicolumn{3}{|c|}{ Partial Correlation } & \multirow{2}{*}{$\frac{A C}{0.645}$} & \multirow{2}{*}{$\begin{array}{l}\text { PAC } \\
0.645\end{array}$} & \multirow{2}{*}{$\begin{array}{c}\text { Q-Stat } \\
29.553\end{array}$} & \multirow{2}{*}{ Prob } \\
\hline 1 & & 1 & $\square$ & 1 & & & & \\
\hline 1 & $\Longrightarrow$ & 1 & & 2 & 0.707 & 0.498 & 65.584 & 0.000 \\
\hline 1 & 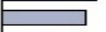 & I & 马ו & 3 & 0.643 & 0.211 & 95.818 & 0.000 \\
\hline 1 & $\square$ & 1 & 1 & 4 & 0.596 & 0.038 & 122.26 & 0.000 \\
\hline 1 & 更 & 10 & 1 & 5 & 0.535 & -0.058 & 143.86 & 0.000 \\
\hline 1 & 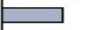 & 1 든 & 1 & 6 & 0.466 & -0.107 & 160.56 & 0.000 \\
\hline 1 & $\square$ & 1 口 & 1 & 7 & 0.380 & -0.154 & 171.84 & 0.000 \\
\hline I & $\square$ & 10 & I & 8 & 0.334 & -0.065 & 180.68 & 0.000 \\
\hline 1 & $\square$ & 1 & 1 & 9 & 0.320 & 0.106 & 188.93 & 0.000 \\
\hline 1 & $\square$ & 1 & I & 10 & 0.245 & 0.026 & 193.87 & 0.000 \\
\hline I & פו & I & I & 11 & 0.200 & -0.037 & 197.22 & 0.000 \\
\hline 1 & • & 1 & 1 & 12 & 0.168 & -0.017 & 199.63 & 0.000 \\
\hline 1 & 曰 & 1 & 1 & 13 & 0.164 & 0.062 & 201.96 & 0.000 \\
\hline 1 & 51 & 1 당 & 1 & 14 & 0.070 & -0.136 & 202.39 & 0.000 \\
\hline I & 51 & 1 & 1 & 15 & 0.083 & -0.027 & 203.01 & 0.000 \\
\hline 1 & {$[1$} & I & 1 & 16 & 0.019 & -0.033 & 203.05 & 0.000 \\
\hline 1 & 1 & 1 & I & 17 & -0.000 & -0.022 & 203.05 & 0.000 \\
\hline 1 & 1 & 1 & 1 & 18 & -0.006 & 0.037 & 203.05 & 0.000 \\
\hline 1 & 1 & 1 & 1 & 19 & -0.033 & 0.036 & 203.16 & 0.000 \\
\hline 10 & 1 & 1 & 1 & 20 & -0.034 & 0.061 & 203.27 & 0.000 \\
\hline 1 뭉 & 1 & $\square$ & 1 & 21 & -0.131 & -0.222 & 205.02 & 0.000 \\
\hline 10 & 1 & 1 & 1 & 22 & -0.051 & 0.048 & 205.29 & 0.000 \\
\hline 10 & 1 & 1 & I & 23 & -0.106 & 0.040 & 206.48 & 0.000 \\
\hline 1 且 & 1 & 1 - & I & 24 & -0.132 & -0.092 & 208.37 & 0.000 \\
\hline 1 ㅁ & 1 & 1 & I & 25 & -0.123 & 0.003 & 210.04 & 0.000 \\
\hline 1 다 & 1 & 1 & 1 & 26 & -0.144 & 0.023 & 212.40 & 0.000 \\
\hline 1 마 & 1 & 1 & 1 & 27 & -0.145 & 0.018 & 214.86 & 0.000 \\
\hline I & 1 & $1 \square$ & 1 & 28 & -0.164 & -0.103 & 218.07 & 0.000 \\
\hline
\end{tabular}

Source: Authors' presentation by using the EViews 7 program 
The results of the ADF test after the transformation of the original series point to the value of 9.276116 , which is greater than the value of the $5 \%$ level, which confirms the alternative hypothesis of the absence of unit roots, i.e. stationarity of the selected time series (Table 3.).

Table 3. ADF test for D (Logproduction)

Null Hypothesis: D(LOGPRODUCTION) has a unit root

Exogenous: Constant

Lag Length: 1 (Automatic - based on SIC, maxlag=10)

\begin{tabular}{lccc}
\hline \hline & t-Statistic & Prob. $^{*}$ \\
\hline \hline Augmented Dickey-Fuller test statistic & -9.276116 & 0.0000 \\
\hline Test critical values: & $1 \%$ level & -3.534868 & \\
& $5 \%$ level & -2.906923 & \\
& $10 \%$ level & -2.591006 & \\
\hline \hline
\end{tabular}

*MacKinnon (1996) one-sided p-values.

Source: Authors' presentation by using the EViews 7 program

Estimation phase refers to the model creation that will, after diagnostics, be reduced to a single model that would apply to forecasting corn production in Serbia in the future. In order to obtain more efficient ARIMA model, special attention will be paid to the selection of autoregressive variables (lags - dependent variable) and moving average (lags- values of residuals). During the research, 100 models with different combinations of AR and MA variables were examined. According to the values of the Akaike and Schwarz tests, the most acceptable model was AR (1) MA (1) MA (2), i.e. $(1,1,1,2)$ model (Table 4.).

Table 4. AR(1) MA(1) MA(2) model statistics

\begin{tabular}{|c|c|c|c|c|}
\hline \multicolumn{5}{|c|}{$\begin{array}{l}\text { Dependent Variable: D(LOGPRINOS) } \\
\text { Method: Least Squares } \\
\text { Date: } 11 / 28 / 15 \text { Time: } 19: 08 \\
\text { Sample (adjusted): } 19492014 \\
\text { Included observations: } 66 \text { after adjustments } \\
\text { Convergence achieved after } 13 \text { iterations } \\
\text { MA Backcast: } 19471948\end{array}$} \\
\hline Variable & Coefficient & Std. Error & t-Statistic & Prob. \\
\hline $\begin{array}{c}C \\
\operatorname{AR}(1) \\
M A(1) \\
M A(2)\end{array}$ & $\begin{array}{r}0.007826 \\
-0.897398 \\
0.244301 \\
-0.711934\end{array}$ & $\begin{array}{l}\text { o.004149 } \\
\text { o.050043 } \\
\text { o.100202 } \\
0.093321\end{array}$ & $\begin{array}{r}1.886214 \\
-17.93253 \\
2.438079 \\
-7.628905\end{array}$ & $\begin{array}{l}\text { o.0640 } \\
\text { o.0000 } \\
\text { o.0176 } \\
\text { o.0000 }\end{array}$ \\
\hline $\begin{array}{l}\text { R-squared } \\
\text { Adjusted R-squared } \\
\text { S.E. of regression } \\
\text { Sum squared resid } \\
\text { Log likelihood } \\
\text { F-statistic } \\
\text { Prob(F-statistic) }\end{array}$ & $\begin{array}{l}0.518614 \\
0.495321 \\
0.115413 \\
0.825848 \\
50.92301 \\
22.26489 \\
0.000000\end{array}$ & \multicolumn{2}{|c|}{$\begin{array}{l}\text { Mean dependent var } \\
\text { S.D. dependent var } \\
\text { Akaike info criterion } \\
\text { Schwarz criterion } \\
\text { Hannan-Quinn criter. } \\
\text { Durbin-Watson stat }\end{array}$} & $\begin{array}{r}0.007819 \\
0.162460 \\
-1.421909 \\
-1.289203 \\
-1.369471 \\
2.178038\end{array}$ \\
\hline $\begin{array}{l}\text { Inverted AR Roots } \\
\text { Inverted MA Roots }\end{array}$ & $\begin{array}{r}-.90 \\
.73\end{array}$ & -.97 & & \\
\hline
\end{tabular}

Source: Authors' presentation by using the EViews 7 program 
At the model diagnostics stage, the validity of the chosen model is evaluated on the basis of its compatibility with the basic data and its predictive power. According to the histogram and correlograms (Q-statistics and residual root), it is noted that the selected model has normal distribution of residuals, whose value of autocorrelation and partial correlation indicates the random movement of residuals (Figure 3.).

Figure 3. Model histogram

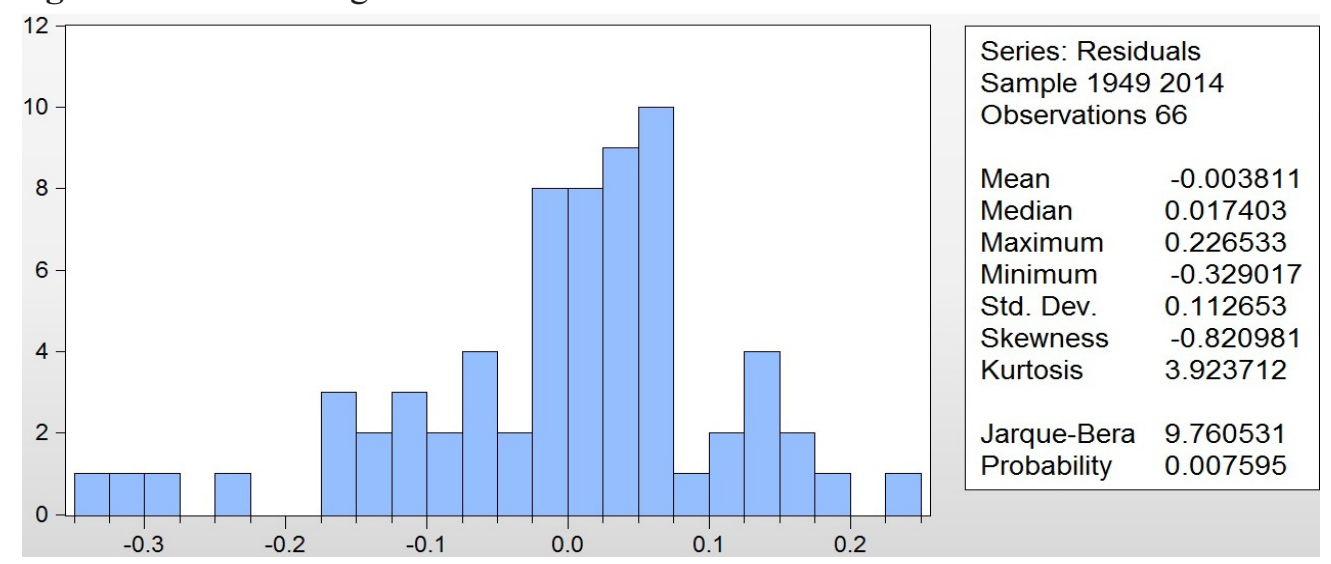

Source: Authors 'presentation by using the EViews 7 program

Justification of the accepted model is also proven by key parameters obtained during the model diagnostics phase - the coefficient of determination $\left(\mathrm{R}^{2}\right)$, the value of DurbinWatson statistics, and significance of F statistic.

$$
\begin{gathered}
\text { Production }=0,008-0,897 \text { Production }_{\mathrm{t}-1}+0,244 \varepsilon_{\mathrm{t}-1}-0,712 \varepsilon_{\mathrm{t}-2} \\
\mathrm{R}^{2}=52 \% \\
\mathrm{DW}=2.18 \\
\text { Prob }(\text { F-statistic })=0,000
\end{gathered}
$$

Another indicator in favor of the model is the heteroscedasticity test (White test), whose value (9.638367) is less than the critical value of $\chi_{(0.05: 14)}^{2}$ which is 23,685 . The assertion of the homogeneity of model variance is accepted (Table 5.). This has shown that the model cannot be further expanded and used for the purpose of long-term forecasts.

Table 5. White test - model heteroskedasticity test

Heteroskedasticity Test: White

\begin{tabular}{llll}
\hline \hline F-statistic & 0.622963 & Prob. F(14,51) & 0.8334 \\
Obs*R-squared & 9.638367 & Prob. Chi-Square(14) & 0.7881 \\
Scaled explained SS & 12.89968 & Prob. Chi-Square(14) & 0.5344 \\
\hline \hline
\end{tabular}

Source: Authors 'presentation by using the EViews 7 program 
In order to forecast the future trend of production, the original number of observations is modified in respect of the length of forecast horizon. Given the tendency of production forecasting by 2017, the following graph is obtained, which incorporates three future corn production scenarios, where the optimistic and pessimistic scenarios are defined as \pm 2 standard errors of real production trends (Graph 2.).

Graph 2. Three future corn production scenarios 2015 -2017

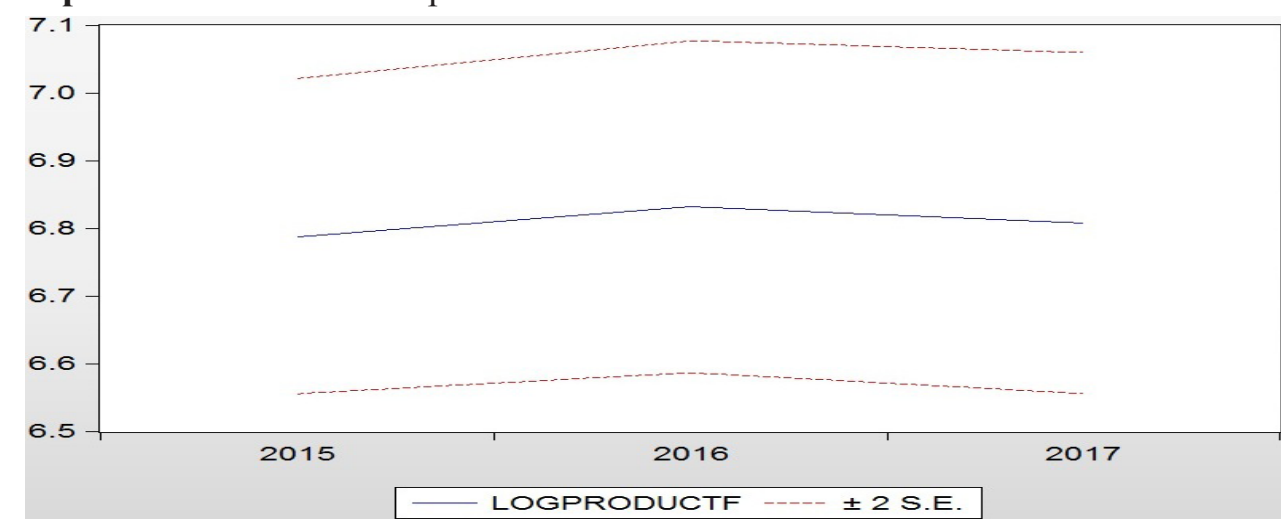

Source: Authors 'presentation by using the EViews 7 program

The final graph of corn production trend in Serbia shows the actual and projected values for the period 1947-2017 and a noticeable decline in production in the coming years, compared with the achieved record production in 2014 (Graph 3.). In relation to the ten-year average corn production, the predicted values of the same are at the same level. Following the production trend from 1947 until the 1980s, an upward trend over the years can be seen, while from the 1980s onwards, stagnant trend is observed, with some extremely positive peaks (1986 and 2014).

Graph 3. Corn production trend in Serbia in the period $1947-2017$

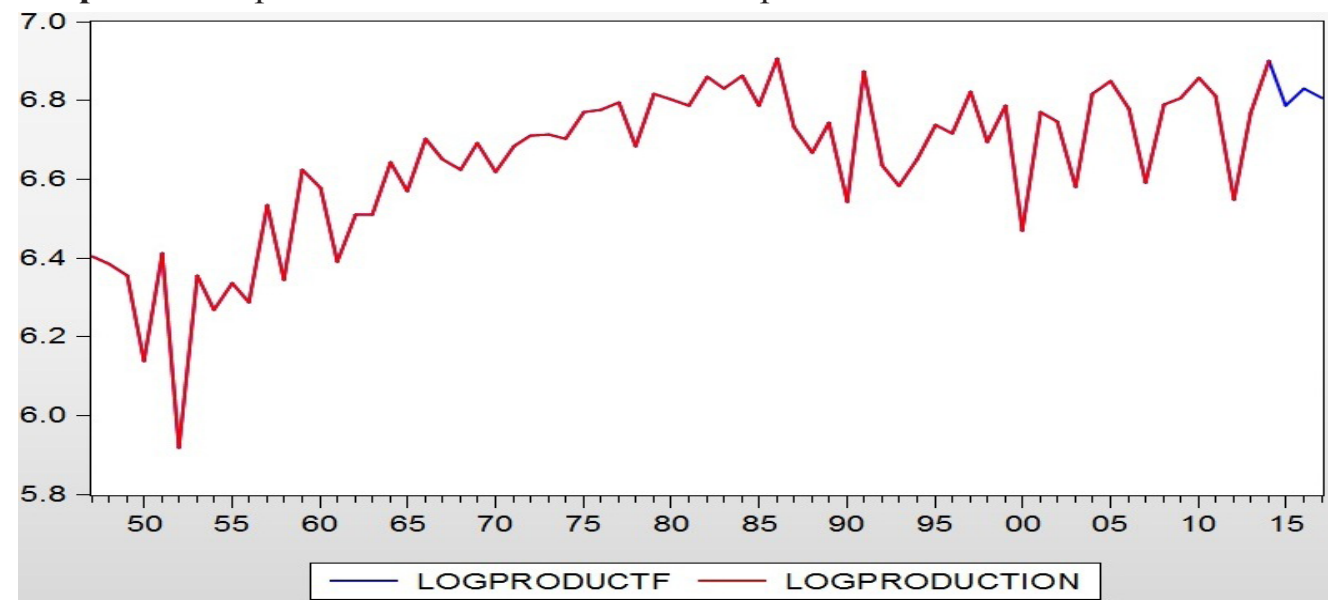

Source: Authors' presentation by using the EViews 7 program

EP 2016 (63) 4 (1141-1156) 
The forecasted corn production in Serbia for the coming years is given in Table 6 . The future production is expected to decrease due to the effects of climate change and frequent extremely dry periods during the year. Drought and high air temperatures are, in addition to fertile land and hybrid seed, the crucial factor for the corn production, which is confirmed by the fact that corn in our country is grown in rainfed conditions, so that yield is highly dependent on the distribution of rainfall during the growing season (Ranđelović et al., 2010).

Another evidence of climate change is the study that has shown the tendency of growth of air temperature and decrease in rainfall over the past thirty years (Bursać et al., 2015). The problem of irrigation of areas planted under corn also affects its production over the years. A very small percentage of areas, only about 3\%, is irrigated in Serbia (Serbian Chamber of Commerce, 2014). If this climate trend continues, it is necessary to implement certain agro-technical measures in order to maintain agricultural production in the future.

Table 6. The forecasted corn production in Serbia from 2015 to 2017.

\begin{tabular}{|l|r|}
\hline Year & Production in million tones \\
\hline 2015 & $6.131 .560,25$ \\
\hline 2016 & $6.778 .631,10$ \\
\hline 2017 & $6.410 .471,89$ \\
\hline
\end{tabular}

Source: Authors'independent presentation

The selected model can be justified because the forecasted corn production trend in Serbia is downward, which is consistent with the action of the above-mentioned influence factors and the real picture that has recently manifested itself in corn production in 2015.

\section{Conclusion}

Serbia has a large agricultural sector, whose potential is based on high-quality arable land and continental climate, favorable for cultivating a large number of crops. Bearing in mind the share of crop production in total agricultural production, Serbian economy can base its growth on it, and achieve significant export activity. The development of agriculture is a crucial opportunity for the economic prospects of Serbia and the achievement of sustainable economic development.

Corn is the most important cash crop in Serbia due to the acreage it covers, whose share in areas under crops has been growing over the years. The average corn production in Serbia is sufficient to meet domestic needs, with significant quantities remaining for export. Based on the amount of corn that is exported, our country has been among the top ten world exporters for many years. More specifically, Serbia can be said to be a significant producer of corn on a global scale. According to Index Mundi, based on corn production, in 2014 Serbia was the $14^{\text {thin }}$ the world, with a yield of 7.7 million tons. 
Forecasting the future corn production in Serbia depends on a number of external factors that are influencing the production process. Based on ARIMA models developed for forecasting corn production by 2017, conclusion about stagnant trend over the years can be drawn. By 2017, corn production is projected to fall by almost $20 \%$, compared to 2014. The cause of this situation may be change in the climate, i.e. the extremely dry period with high temperatures. Therefore, a decline in export volumes can be expected, as well as of the value of exports which is significant for our economy. In addition, the level of cattle feed will decrease as well, which ultimately affects the production of pork in Serbia. The only way to avoid the forecast of a decline in future corn production is the adaptation of agricultural production to new conditions and improving corn production in the direction of increasing its resistance to external factors.

\section{Literature}

1. Akpanta, A.C., Okorie, I.E. (2015): On the Time Series Analysis of Consumer Price Index data of Nigeria - 1996 to 2013, American Journal of Economics, vol. 5, no. 3, pp. 363-369 (available at: http://article.sapub.org/10.5923.j.economics. 20150503.08. $\mathrm{html}$ )

2. Baldigara, T., Mamula, M. (2015): Modelling international tourism demand using seasonal ARIMA models, Tourism and Hospitality Management, vol. 21, no. 1, pp. 9-31 (available at: https://www.researchgate.net/publication/279225215_Modelling international_tourism_demand_using_seasonal_arima_models)

3. Borojević, S. (1991): Principi i metodi oplemenjivanja bilja, Naučna knjiga, Beograd, Srbija

4. Box, G., Jenkins, G. (1970): Time Series Analysis: Forecasting and Control, San Francisco: Holden-Day

5. Bursać, M.N., Ivanović, R., Nikolić, M. (2015): Agricultural production in the Niš valley-agroclimatic conditions, Teme, no. 1, pp. 275-289 (available at: http://teme2. junis.ni.ac.rs/index.php/TEME/article/view/2/34)

6. Etuk, E. H. (2012): Seasonal ARIMA model to Nigerian Consumer Price Index Data, American Journal of Scientific and Industrial Research, vol. 3, no. 5, pp. 283-287. (available at: http://www.scihub.org/AJSIR/PDF/2012/5/AJSIR-3-5-283-287.pdf)

7. Glamočlija, Đ., Blažić, M., Živanović, Lj., Ikanović, J. (2007): Proizvodnja kukuruza u uslovima intenzivne ishrane biljaka azotom. Zbornik radova XXI savetovanja agronoma, veterinara i tehnologa, Beograd, vol. 12, no. 1-2, pp. 31-45 (available at: http://www.pkbae.rs/files/pdf/2007-vol1-2.pdf)

8. Đekić, S. (2010): Agrarni menadžment, Ekonomski fakultet u Nišu, Niš, Srbija 9. Iqbal, N., Bakhsh, K. H. U. D. A., Maqbool, A. S. I. F., Ahmad, A. S. (2005): Use of the ARIMA model for forecasting wheat area and production in Pakistan, Journal of agriculture \& Social sciences, vol. 1, no. 2, pp. 120-122. (available at: https://www. academia.edu/705606/Use_of_the_ARIMA_model_for_forecasting_wheat_area_ and_production_in_Pakistan)

EP 2016 (63) 4 (1141-1156) 
10. Kostić, Z., Lepojević, V., Janković-Milić, V. (2016): Modeling monthly inflation in the Republic of Serbia, measured by consumer price index, Facta Universitatis, Series: Economics and Organization vol. 13, no. 2, pp. 145-159. (available at: http://casopisi. junis.ni.ac.rs/index.php/FUEconOrg/article/view/1742/1266)

11. Lekić, S., Mirić, M., Petrović, R., Dražić, S., Stančić, I. (2004): Tehnologija proizvodnje semena, Društvo selekcionera i semenara Republike Srbije, Beograd, Srbija

12. Marković, I., Marković, M. (2014): Agricultural protectionism of the european union in the conditions of international trad liberalization, Economics of Agriculture, no. 2, pp. 423-440 (available at: http://ageconsearch.umn.edu/bitstream/ 175292/2/11\%20 EP\%202\%202014-11.pdf)

13. Mladenović, J., Lepojević, V., Janković-Milić, V. (2016): Modelling and Prognosis of the Export of the Republic of Serbia by Using Seasonal Holt-Winters and Arima Method, Economic themes vol. 54, no. 2, pp. 233-260. (available at: https:// www.degruyter.com/downloadpdf/j/ethemes.2016.54.issue-2/ethemes-2016-0012/ ethemes-2016-0012.xml)

14. Olanrewaju, K. O., Olakunle, O. A., Emmanuel, A. O. (2014): Forecast Performance of Multiplicative Seasonal Arima Model: an Application to Naira/ Us Dollar Exchange Rate, American Journal of Applied Mathematics and Statistics, vol. 2, no. 3, pp. 172178. (available at: http://pubs.sciepub.com/ajams/2/3/14/)

15. Okasha, K.M., Abu Shanab, M.M.D. (2014): Forecasting Monthly Water Production in Gaza City Using a Seasonal ARIMA Model Scholars Journal of Physics. Mathematics and Statistics, vol. 1, no. 2, pp. 61-67 (available at: http://saspjournals.com/wp-content/ uploads/2014/11/SJPMS-1261-70.pdf)

16. Ranđelović, V., Prodanović, S., Despotović, S., Glamočlija Đ. (2010): Prinos kukuruza različitih FAO grupa zrenja u funkciji padavina tokom ASI perioda, Zbornik radova XXIV savetovanja agronoma, veterinara i tehnologa. Beograd, vol. 16, no. 1-2, pp. 103-111(available at: http://www.pkbae.rs/files/pdf/2010VOL1_2.pdf)

17. Vasquez, R., (2011): Introducción a los modelos ARIMA, Series de tiempo Modelos ARIMA.

18. Sabovljević, R., Aćimović, B., Simić, D., Goranović, Đ., Milosavljević, S., Stanković, Z. (2008): Varijabilnost $i$ korelacije promena tokom klijanja hibridnog semena kukuruza. V Simpozijum iz Selekcije i Semenarstva, Vrnjačka Banja

19. Subić, J., Popović, V. Ž., Vuković, P. (2005): Održivo korišćenje zemljišta u poljoprivredi. Ekonomika Poljoprivrede, vol. 51, no. 5-6, pp. 26-35

20. Tabaković, M. (2012) Uticaj vremenskih uslova, zemljišta i genotipske kombinacije na osobine hibridnog semena kukuruza, Poljoprivredni fakultet Beograd, Beograd, Srbija

21. Agricultural Marketing Information System of Serbia http://www.stips.minpolj. gov.rs/ (20.2.2016.) 
22. Agriculture and Rural Development Strategy of the Republic of Serbia for the period 2014-2024,http://uap.gov.rs/wp-content/themes/uap/STRATEGIJA\%2020142020\%20.pdf (22.2.2016.)

23. Index Mundi (2014) Corn Production by Country in $1000 \mathrm{MT}$, http://www. indexmundi.com/agriculture/?commodity=corn (25.2.2016.)

24. International Grains Council, http://www.igc.int/en/downloads/grainsupdate/ IGC_5yearprojections2015.pdf (03.3.2016.)

25. Serbian Chamber of Commerce http://www.pks.rs/PrivredaSrbije.aspx?id=13 (07.3.2016.)

26. Statistical Office of the Republic of Serbia http://webrzs.stat.gov.rs/WebSite/Public/ PageView.aspx?pKey=138 (10.3.2016.)

27. Žita Srbije http://www.zitasrbije.rs/ (17.2.2016.)

28. The Statistic Portal, 2015 http:/www.statista.com/statistics/254299/top-globalcorn-exporters/ (15.3.2016.) 


\title{
PROGNOZIRANJE PROIZVODNJE KUKURUZA U SRBIJI PRIMENOM ARIMA MODELA
}

\author{
Ivana Ilićt, Sonja Jovanovićs ${ }^{4}$,Vesna Janković Milićc
}

\begin{abstract}
Rezime
Poljoprivredna biljna proizvodnja usko je povezana sa klimom kao odlučujućim faktorom uspeha. Temperaturne fluktuacije i promene obima padavine glavni su faktori koji utiču na rast i razvoj biljaka u krajnjem i na proizvedenu količinu. Kukuruz je najzastupljenija biljna vrsta, neophodna za obezbeđivanje domaćih potreba, kao i strateški proizvod namenjen izvozu. Proizvodnja kukuruza je u periodu od 1947 2014. godine u Srbiji imala oscilatorni trend sa značajnim skokovima i padovima $u$ proizvodnji. Predmet ovog rada je predvideti buduće kretanje proizvodnje kukuruza u Srbiji. Nadovezujući se na predmet, cilj rada je modelirati model po kome je moguće prognozirati proizvodnju kukuruza za naredni period i utvrditi trend njenog kretanja.
\end{abstract}

Ključne reči: proizvodnja kukuruza, izvozne šanse, Box Jekins metodologija, ARIMA model, Srbija

4 Master ekonomista Ivana Ilić, student doktorant,Univerzitet u Nišu, Ekonomski fakultet Niš, Trg kralja Aleksandra Ujedinitelja br. 11, Niš, Srbija, Telefon: +381 645734 347, E-mail: ivanica1404@yahoo.com

5 Vanredni profesor, dr Sonja Jovanović, Univerzitet u Nišu, Ekonomski fakultet Niš, Trg kralja Aleksandra Ujedinitelja br. 11, Niš, Srbija, Telefon: +381 18528 655, E-mail: sonja.jovanovic@eknfak.ni.ac.rs

6 Vanredni profesor, dr Vesna Janković Milić, Univerzitet u Nišu, Ekonomski fakultet Niš, Trg kralja Aleksandra Ujedinitelja br. 11, Niš, Srbija, Telefon: +381 18528 655, E-mail: vesna.jankovic@eknfak.ni.ac.rs 